Journal of Urban and Regional Analysis,

vol. XIII, 2, 2021, p. 215 - 232

https://doi.org/10.37043/JURA.2021.13.2.2

\title{
THE SECOND-BEST OPTION METHOD IN REGIONAL ANALYSIS: THREE APPLICATIONS
}

\author{
Antoni Francesc TULLA, Ana VERA, Gloria Elizabeth VELOZ \\ Universitat Autònoma de Barcelona, Bellaterra, Spain
}

\begin{abstract}
Inequalities between regions frequently mean that some are highly competitive while others are neglected because they do not produce socially demanded goods. Nevertheless, in the framework of sustainable local development, each territory could engage in some economic activities even if other areas are better prepared for them, when these represent the best specialization in which the territory in question can engage in. The existence of a Second-Best Option (SBO) in a territory means successfully promoting one or more economic activities that allow a comparative advantage, which means generating significant added value with the transformation of products that incorporate knowledge, technology, and innovation. The main contributions of the theory of comparative value and of the SBO method are discussed. Qualitative and quantitative methods are used instead of just the latter, as it happens in economics. In the three cases studied, activities similar to SBO have been found, favoured by the following conditions: added value, innovation, infrastructure, and better access to markets.
\end{abstract}

Key Words: added value, comparative advantage, second-best option (SBO), sustainable local development (SLD), Kichwa people of Rukullakta, Andorra, Catalan High Pyrenees.

\section{Introduction}

Regional inequalities caused by globalization of markets have led to the abandonment of large rural areas and concentration in regions that are more competitive in producing goods and services. This situation could be changed if it is understood that each region could offer some activity for which it is suited, when it is accepted that there are social, cultural, environmental, and even economic costs such as depopulation and neglect of the territory (Mocanu et al. 2018). In some peripheral regions like Eastern Macedonia and Thrace (Greece), a wellimplemented Common Agricultural Policy (CAP) has improved the comparative advantage (Markopoulos 2019), which has allowed the introduction of innovative activities with greater added value. Moreover, the introduction of "green shoots" favours a better environmental protection and the promotion of local economic, social, and environmental development. We aim to demonstrate that regions have a second-best option (SBO) which, with the theory of comparative advantage, could lead to viable activities in every case (Tulla et al. 2009). Each area could engage in these, even if others are better equipped for them, when they represent the best specialization open to that particular territory (Tulla 2019).

The incorporation of operations that transform raw materials represents a new product of greater value. This would be the case with wood obtained from a forest, which could be converted for several uses: raw material as such, construction material, furniture making, etc. However, if a furniture factory or artisanal workshops are established in the same region, more local employment and added value are produced. The same thing happens with services like tourism. If the landscape of a region is valued, hotels, guide services, sustainable means of transport, and so on, are established, thus generating added value that will support the 
sustainable local development (SLD), as a greater part of the income from the end product remains in the same territory (Vera et al. 2011).

The principle of comparative advantage, using the SBO method, is based on three assumptions: (1) space is a scarce resource that requires decisions to be made about the best location of activities; (2) each territory has a relative superiority over other territories in engaging in certain activities; and (3) there is always a second location which, although it may not be the best, can also accommodate the activities. Moreover, in many agricultural areas, there is a dual land market that rules out the free market competition and it makes land-use planning advisable (Nel-Lo 2010). Price is frequently generated from the side of demand, and, in rural areas, the supply of land involves setting the prices in keeping with the capacity of the buyer, who might have income from an urban activity. Building a hotel or second home, for example, brings higher prices than agricultural uses. This confirms the need for public regulation like that in the defence of the property of indigenous communities in Ecuador, as set in their 2016 Organic Law on Rural Lands and Ancestral territories.

A brief account of the state-of-the art is given, along with a description of the SBO methodology, and its application in the Catalan High Pyrenees (CHP) in Spain, with the Kichwa People of Rukullakta, Ecuador (KPR), and in the Principality of Andorra (PA). Activities that might be regarded as SBO and the techniques used in their application are considered.

\section{State-of-the Art}

The classical school's principle of comparative advantage affirms that each territory will specialize in the goods and services that it is best equipped to produce, rather than all those territory needs (Tulla et al. 2009). A brief account of the contributions of some authors supports our approach. Ricardo (1817) says that the costs of producing goods are defined by the natural conditions and the historical development, which generates differential income derived from the varying qualities of soil and the available natural resources. Von Thünen (Hall 1966) incorporates the localization and transport costs to this analysis by including the different incomes deriving from localization. The most intensive agricultural activities are located near the market or towns in order to reduce transport costs. A major advance is the model formulated by Heckscher (Findlay et al. 2016) and Ohlin (1933), which stresses the levels of technology and knowledge of the factors of production in each region and it considers the added value that this brings for the first time. Hence, a territory will tend to export goods and services that require intensive factors with which it is well endowed, while seeking to import those needing intensive factors which it does not have. This entails capital investment in training and acquiring machinery. Furthermore, the artisanal knowledge of the European rural population (Fuller 1990) or that regarding crops and medicinal plants of indigenous communities in Latin America could also be seen as having value (Gray et al. 2008).

Olsen (1971) suggested that a relative advantage exists for each region, which can be measured by the opportunity cost of not specializing in the production of goods and services for which it is best equipped or more skilled, although other regions could do better because, as he points out, if you do not want to close a territory, everyone should be engaged in some activity. Moreover, if these products or services do not exist in a region, then they must be imported. Opportunities for peripheral regions appear when negative effects are caused in developed areas by increasing agglomerations and consequent diseconomies, thus giving rise to development inequalities, as Myrdal (1957) described with his centre-periphery theory. Peripheral regions then have the chance to localize economic activities of comparative advantage in relation with the big production and distribution centres, with a network of innovative small- and medium-sized businesses, supported by spatial loyalty among the economic and social agents of each territory (Pallares-Barbera et al. 2004).

The dilemma posed by the balanced and unequal development suggests the possibility that some peripheral regions could have 'a comparative advantage' in certain goods and services. 
For example, in the CHP, it has been shown that the transformation of certain dairy products, extensive ecological livestock farming, environmentally-friendly tourist activities, like crafts, hiking, and cross-country skiing, as well as cultural attractions based on the historical, social, and heritage wealth of the Pyrenees, can produce a comparative advantage as SBO (Tulla 2019). And also, Social Farming could create an SBO with comparative advantage (Tulla et al. 2014). In Latin America, the same is true for the cacao production on indigenous lands (De Marco Larrauri et al. 2016), while Andorra's fiscal conditions favour the commercial and finance sectors as economic drivers (Bricall et al. 1975, Bricall et al. 2001), together with the tourist sector, which is based on skiing in winter and activities in natural spaces and heritage areas in the summer, as SBO activities (Pou Serradell 2005).

The SBO method could be applied to different situations where it is necessary to combine the trends of globalisation with respect for and maintenance of traditional activities. This would be the case of transhumance in Romania (O'Brien and Creţan 2019), which has a cultural identity and historical tradition that could be protected, thus preserving the livestock activity in rural areas that are at risk of depopulation. SBO is not explained by economic factors alone. Also, important are the cultural, social and, in general, the humanist elements that strengthen the identity-defining characteristics of a territory (Tulla 2019). Furthermore, we find the resistance, with local development projects, of industrial areas in disadvantaged regions (lanoş 2000), as happened with the Roşia Montană mining project which has involved a process of relocation and new settlements to favour foreign investment (Vesalon and Creţan 2012), although without obtaining the expected results. Small businesses and cooperatives should be encouraged and family initiatives that stimulate new, value-added tourist and craft activities should be supported. Thus, the social risks of foreign investment in Romania's disadvantaged areas have exacerbated regional inequalities rather than reducing them (Creţan et al. 2005).

Opportunities for interacting with other areas can also favour local development as would be the case of corridors penetrating regions with different levels of development. One possibility in this regard could be the anisotropic spaces that have been studied in West Romania (Creţan et al. 2016) or the airports in the medium-sized and small cities, which can open up new possibilities for the mobility of people and goods (Creţan et al. 2009) and, thus, they favour local development. Another factor that should be considered is that the strategic decisions of political powerholders, promoting investment in megaprojects, like hydroelectric power plants (Creţan and Vesalon 2017), can have a multiplier effect favouring regional development. Nevertheless, these decisions can be constrained by the levels of corruption of local, regional, or state elites with a negative result for the local population (Creţan and O'Brien 2020).

\section{Methodology}

\section{Study areas}

The SBO method has been applied in three territories, the Catalan High Pyrenees (CHP), the Principality of Andorra (PA), and the territory of the Kichwa People of Rukullakta (KPR). The CHP (Fig. 1), in the northeast of Catalonia (Spain) covers an area of $5,776 \mathrm{~km}^{2}$ and 71,637 inhabitants (2017), distributed among six districts (Idescat 2018) to which the SBO method is applied. The PA is a sovereign state covering an area of $468 \mathrm{~km}^{2}$ and 74,794 inhabitants (2017), distributed among seven municipalities (parroquies), as units of analysis. The KPR, in the Amazonian region of Ecuador, between the cantons of Archidona and Tena in the Napo Province, with 17 communities, covers an area of $424.4 \mathrm{~km}^{2}$ and 6,735 inhabitants (2018). In the first two cases, the analysis covers all sectors, while in the KPR it focuses on agricultural, livestock and forestry $A \& L U$, an approach which requires previous consideration on the physical limitations of the territory and its accessibility to markets.

The concept of SBO was formulated by Lipsey and Lancaster (1956), who presented it as satisfying in the conditions of Pareto optimality (Bohm 1987), when only one of the three necessary conditions is missing. Later, Boadway (1994) adapted the SBO theory to the public 
economy and taxes, considering aggregate data, temporary circumstances, and exogenous factors. This method was also used in the search for a workable legal system (Markovits 1997) or a second-best legislation like the anti-trust laws (Hulen 1998) which would make it possible to promote more local initiatives. Lipsey and Lancaster (1956) believed that in order to obtain an SBO, statistics at regional level need to be collected and models must be formulated using the econometric analysis (Lipsey 2007). However, in our analysis, we take the conceptual notion to apply it - apart from the economic calculation - with a qualitative and/or quantitative methodology, to the territorial analysis. We then consider that some conditions might be missing for the development of profitable activities and services in a peripheral area. It might be that the soil is not very fertile or that some activity is absent in planning an SBO based on the complementarity of functions in a region. The qualitative methodology offers a better understanding of the area's activities from a more time-bound perspective, and it also allows the evaluation of more important activities in order to apply the SBO method. Our approach is bolstered by the comments of Smith (1977), and Lee and Smith (2004), regarding Vilfredo Pareto's contribution to welfare economics and geography. They believe that Pareto offers criteria for efficiently locating activities or equally distributing resources, thus introducing a certain ethics, but also recognizing that the contribution is limited by theoretical constraints since it is considering a non-growth economy, although they do note that, with due precautions, it could be useful for applications that include the comparative advantage.

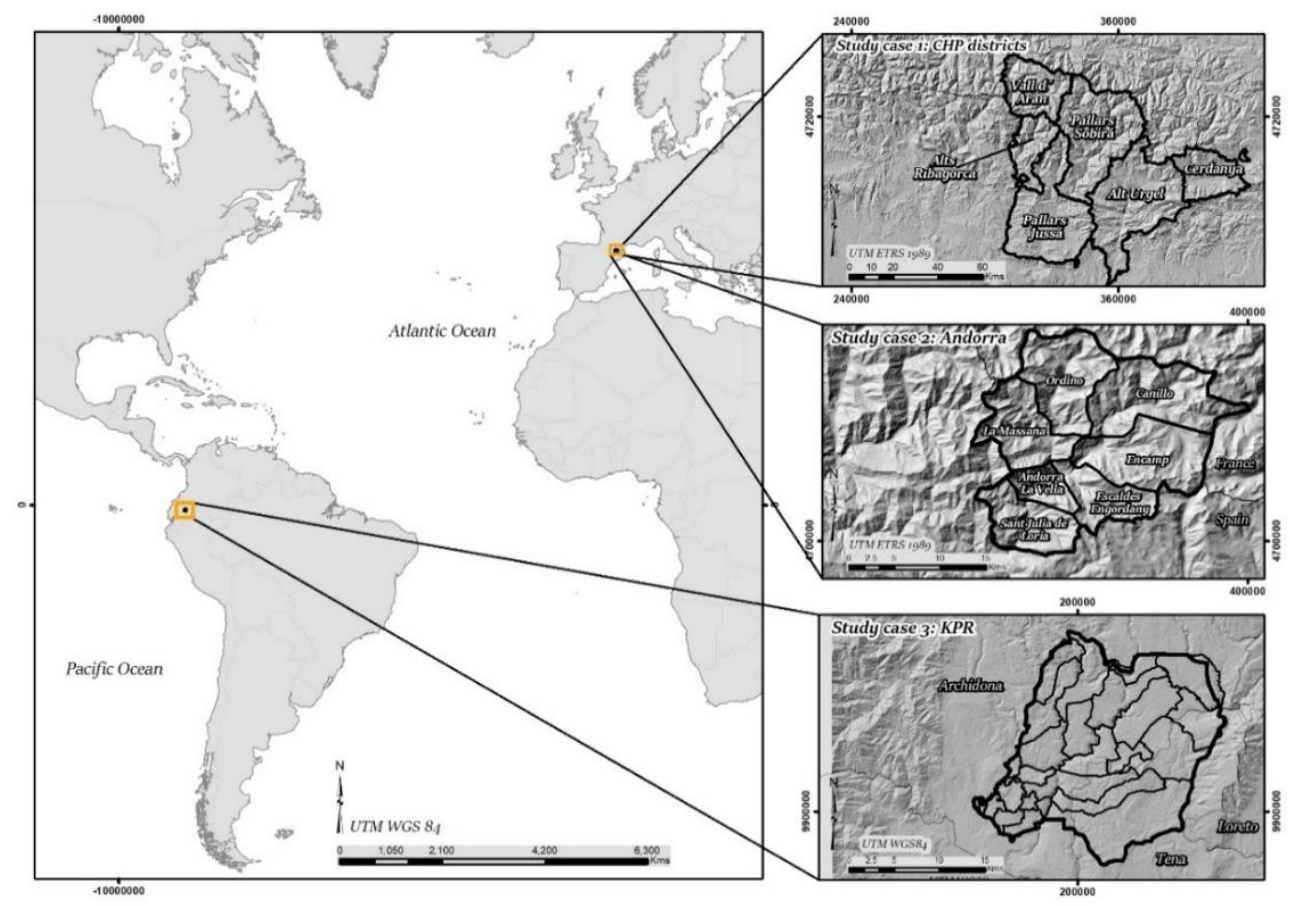

Fig. 1 - Location of case studies

Source: the Authors, using atlases showing Catalonia, Andorra and Ecuador

\section{Application of Second-Best Option}

In our methodological approach (Fig. 2), two of the three conditions for developing the SBO method are set out. The first is accepting that every territory has the right to engage in some kind of activity. The second considers that a territory specializes in what it is best equipped or prepared to do, even if other territories can offer the same product with better economic efficiency. In addition, for example, some items like dairy products, which are found in many places, need to reinforce the SBO with added value and the comparative advantage over 
other territories. However, there are products like ticaso (jungle peanut) and guayasa leaves that exist in only a few places, which can also be used with a better comparative advantage. Undoubtedly, attempts have been made on many occasions to offer substitutes for these rare products with alternative, similar, more economically efficient items, as it is the case of vanilla products in Ecuador. Nevertheless, the economic value cannot be taken as the only yardstick, because social, political, and environmental values must be also considered when efficiency is gauged.

\begin{tabular}{|c|c|c|c|c|}
\hline ACTIVITIES & REGIONS: & & & \\
\hline $\begin{array}{l}\text { AND LAVD } \\
\text { USES }\end{array}$ & A & B & C & \\
\hline First activity & $\%$ & $80 \%$ & $20 \%$ & $\begin{array}{l}\text { maximum value that would be obtained by } \\
\text { localizing a use/activity in a certain area (using } \\
\text { different methods of evaluation). }\end{array}$ \\
\hline Second activity & $50 \%$ & & $40 \%$ & $\begin{array}{l}\text { The reading by columns expresses the best value } \\
\text { of a use/activity for each region within a wider } \\
\text { territorial sphere. }\end{array}$ \\
\hline Third activity & $40 \%$ & $70 \%$ & & $\begin{array}{l}\text { In the rows, the circles are the most appropriate } \\
\text { uses/activities for each area, although there are }\end{array}$ \\
\hline Fourth activity & $60 \%$ & & $30 \%$ & $\begin{array}{l}\text { It is assumed that each region has the conditions } \\
\text { for at least one activitv. }\end{array}$ \\
\hline
\end{tabular}

Fig. 2 - Application of the Second-Best Option Method (SBO) Source: the Authors

We can express SBO as follows: "a territory can successfully engage in an activity, even if other territories are better equipped for them, when this is the best specialization that can be carried out in this territory". Such activities must bear in mind several parameters: (1) they are possible to carry out in the territory because of its natural conditions and human capital, and also because each territory has the right to engage in one or more activities to sustain its population; (2) they are the best activities that can be carried out in this territory; (3) the comparative advantage can be improved in relation with other territories by incorporating the added value into the activities; (4) this means incorporating new kinds of transformation, knowledge, technology, and innovation, but also improvements in marketing and recognition by the Designation of Origin, if this is possible; and (5) achieving a minimum employment and population threshold to allow the consolidation of these activities (Tulla 2019).

In order to explain the SBO method, we choose four activities and land uses (A\&LU) in the rows and three proxy regions (columns). If we assume that each region must have at least one of the activities, then it should choose that for which it is best equipped (Tulla et al. 2009). Different methods can be used to evaluate the positive and negative aspects of localization in each region, and in our case the opinion of focal groups (Morgan 1998, Barbour 2007, Stewart and Shamdasani 2014) is considered, and, also, the territory's economic, social, and natural constraints. A list of activities, potentialities, and limitations is initially drawn up with experts, local actors, and researchers who are participating in the focal group (Krueger 1998, Krueger and Casey 2014). Next, each activity is evaluated on a scale from zero to a hundred, and this must be agreed upon or otherwise it must be the result of the arithmetic mean of the values given for each activity by the members of the focal group. The highest value is $100 \%$ and the other values of the matrix will be a percentage of each activity over the activity with the highest score $(100 \%)$ in all regions. Normally, several focus groups with the local actors and outside experts are used, and separately, in order to avoid the "contaminating opinion effect". 
The SBO method has been applied differently in each case study, depending on the type of data available (Table 1). In the CHP, primary data were obtained using a qualitative method (in-depth interviews and focal groups), which then made it possible to concentrate basically on activities selected by the local actors and experts. However, in the PA, secondary data obtained from the official statistics covering all economic activities have been used, which conditions the results more than the use of data of qualitative origin does. The SBO method applied a quantitative method to select the sectors in each municipality. Finally, in the case of KPR, the two methodologies have been combined in order to find, first, the statistical data in the 2018 TNC (The Nature Conservancy 2018) census and then to compare them by the means of in-depth interviews with experts and focal groups in each community. This analysis combines the bottom-up local orientation with possible regional policies and decisions being taken top-down.

Three types of SBO application method

\begin{tabular}{|c|c|c|}
\hline $\begin{array}{l}\text { HIGH PYRENEES } \\
\text { AND ARAN (CHP) }\end{array}$ & $\begin{array}{l}\text { PRINCIPALITY OF } \\
\text { ANDORRA (PA) }\end{array}$ & $\begin{array}{l}\text { KICHWA PEOPLE OF } \\
\text { RUKULLAKTA (KPR) }\end{array}$ \\
\hline $\begin{array}{l}\text { Local level: } 6 \text { districts } \\
\text { Multisectoral SBO analysis }\end{array}$ & $\begin{array}{l}\text { State level: } 7 \\
\text { municipalities } \\
\text { Multisectoral SBO analysis }\end{array}$ & $\begin{array}{l}\text { Local level: } 17 \text { units (communities) } \\
\text { Sector SBO analysis (Agrarian \& } \\
\text { forest) }\end{array}$ \\
\hline $\begin{array}{l}\text { QUALITATIVE } \\
\text { METHODOLOGY }\end{array}$ & $\begin{array}{l}\text { QUANTITATIVE } \\
\text { METHODOLOGY }\end{array}$ & $\begin{array}{l}\text { QUALITATIVE AND QUANTITATIVE } \\
\text { METHODOLOGY }\end{array}$ \\
\hline $\begin{array}{l}\text { PRIMARY DATA: } \\
\text { Focus groups (11) of 3-6 } \\
\text { persons per district. Five } \\
\text { focus groups of experts and } \\
\text { five other focus groups of } \\
\text { local actors. One mixed } \\
\text { focus group of experts and } \\
\text { local actors. }\end{array}$ & $\begin{array}{l}\text { SECONDARY DATA: } \\
\text { Statistical information } \\
\text { (Government of Andorra } \\
\text { 2018). Establishments by } \\
\text { economic sector (2016); } \\
\text { Wage-earning by } \\
\text { economic sector (2017). }\end{array}$ & $\begin{array}{l}\text { SECONDARY AND PRIMARY DATA: } \\
\text { Statistical data (TNC 2018). Crop } \\
\text { surface (ha) and number of animals or } \\
\text { farms. } \\
\text { Mixed focal groups of experts and } \\
\text { local actors (4-15 persons) in } 17 \\
\text { communities. } \\
\text { Five in-depth interviews with experts. }\end{array}$ \\
\hline $\begin{array}{l}\text { 1) Priority of economic } \\
\text { activities as a result of focus } \\
\text { group discussion. } \\
\text { 2) Analysis of each } \\
\text { economic activity. } \\
\text { 3) Analysis of each district. } \\
\text { 4) SBO as an interaction of } \\
\text { economic activities and } \\
\text { districts. } \\
\text { 5) A basis for producing } \\
\text { local policies. }\end{array}$ & $\begin{array}{l}\text { 1) Priority of economic } \\
\text { activities as a result of } \\
\text { statistical analysis. } \\
\text { 2) Analysis of each } \\
\text { economic activity. } \\
\text { 3) Analysis of each } \\
\text { municipality. } \\
\text { 4) SBO as an interaction } \\
\text { of economic activities and } \\
\text { municipalities. } \\
\text { 5) Producing regional } \\
\text { policies. }\end{array}$ & $\begin{array}{l}\text { 1) Priority of crops, livestock and } \\
\text { forest as a result of statistical analysis. } \\
\text { 2) Validation in focus group } \\
\text { discussion. } \\
\text { 3) Analysis of each crop, livestock and } \\
\text { forest. } \\
\text { 4) Analysis of each community. } \\
\text { 5) SBO as an interaction of agricultural } \\
\text { activities and communities. } \\
\text { 6) Local sectoral policies in a region. }\end{array}$ \\
\hline
\end{tabular}

Source: the Authors, based on the three research cases

\section{Results}

The case of the Catalan High Pyrenees and Aran

In applying the SBO method to the CHP case (Table 2), eleven focal groups consisting of 36 members were constituted, two per district, one with experts and one with local actors, and each group was coordinated by a researcher. The exception was Alta Ribagorça, which had only one group. First, a list of possible A\&LU was drawn up in the focal groups and then it was unified. Then, each group discussed which of these activities would be most appropriate for SLD in the district, considering its ability to produce added value, and making a list of A\&LU showing the percentage of prioritization, with the highest value being given to the most appropriate. Finally, the participants are asked online about the weaknesses and potentialities of each one of the 12 A\&LU in the focal groups of each district, modifying the scores in keeping 
with these opinions. Next, for each activity, the scores received for each district were added up. The table is completed by drawing up an A\&LU/district matrix with percentages showing the maximum value obtained by each activity and district which, in this study, corresponds with ski resorts and mountain housing estates.

Table 2

Application of the SBO method in the Catalan High Pyrenees and Aran (CHP)

\begin{tabular}{|l|c|c|c|c|c|c|c|}
\hline ACTIVITIES AND LAND & \multirow{2}{*}{$\begin{array}{c}\text { Final } \\
\text { USE (A\&LU) }\end{array}$} & \multicolumn{6}{|c|}{ DISTRICTS } \\
\cline { 3 - 8 } & $\begin{array}{c}\text { Alt } \\
\text { Urgell }\end{array}$ & $\begin{array}{c}\text { Alta } \\
\text { Ribagorça }\end{array}$ & Cerdanya & $\begin{array}{c}\text { Pallars } \\
\text { Jussà }\end{array}$ & $\begin{array}{c}\text { Pallars } \\
\text { Sobirà }\end{array}$ & $\begin{array}{c}\text { Era } \\
\text { Aran }\end{array}$ \\
\hline $\begin{array}{l}\text { Cultural activities of } \\
\text { added value }\end{array}$ & $\mathbf{4 9 3}$ & $83 \%$ & $88 \%$ & $\mathbf{8 7 \%}$ & $70 \%$ & $80 \%$ & $85 \%$ \\
\hline $\begin{array}{l}\text { Natural landscape and } \\
\text { rural tourism }\end{array}$ & $\mathbf{4 8 7}$ & $80 \%$ & $\mathbf{9 0 \%}$ & $83 \%$ & $62 \%$ & $77 \%$ & $95 \%$ \\
\hline $\begin{array}{l}\text { Ecological pasture-fed } \\
\text { livestock farming }\end{array}$ & $\mathbf{4 8 1}$ & $87 \%$ & $64 \%$ & $81 \%$ & $\mathbf{8 5 \%}$ & $89 \%$ & $75 \%$ \\
\hline $\begin{array}{l}\text { Value-added adventure } \\
\text { tourism }\end{array}$ & $\mathbf{4 4 8}$ & $94 \%$ & $68 \%$ & $66 \%$ & $73 \%$ & $\mathbf{9 2 \%}$ & $55 \%$ \\
\hline $\begin{array}{l}\text { Value-added milk } \\
\text { production }\end{array}$ & $\mathbf{4 1 1}$ & $\mathbf{9 8 \%}$ & $67 \%$ & $83 \%$ & $57 \%$ & $78 \%$ & $28 \%$ \\
\hline $\begin{array}{l}\text { Ski resorts, second } \\
\text { residences, and hotels } \\
\text { (development) }\end{array}$ & $\mathbf{4 0 4}$ & $61 \%$ & $63 \%$ & $86 \%$ & $18 \%$ & $76 \%$ & $\mathbf{1 0 0 \%}$ \\
\hline $\begin{array}{l}\text { Industries, textile design } \\
\text { and sports materials } \\
\text { services }\end{array}$ & $\mathbf{3 9 8}$ & $\mathbf{8 5 \%}$ & $49 \%$ & $73 \%$ & $51 \%$ & $68 \%$ & $72 \%$ \\
\hline $\begin{array}{l}\text { Installation. Renewable } \\
\text { energy (hydroelectric, } \\
\text { solar, wind) }\end{array}$ & $\mathbf{3 9 7}$ & $\mathbf{7 2 \%}$ & $\mathbf{7 4 \%}$ & $54 \%$ & $72 \%$ & $62 \%$ & $63 \%$ \\
\hline $\begin{array}{l}\text { Sawmills, transformation } \\
\text { of wood, and } \\
\text { construction of pallets }\end{array}$ & $\mathbf{3 7 2}$ & $76 \%$ & $58 \%$ & $69 \%$ & $42 \%$ & $\mathbf{7 3 \%}$ & $54 \%$ \\
\hline $\begin{array}{l}\text { Tourist-oriented } \\
\text { professional and } \\
\text { university training, etc. }\end{array}$ & $\mathbf{3 6 2}$ & $83 \%$ & $36 \%$ & $\mathbf{8 1 \%}$ & $64 \%$ & $51 \%$ & $47 \%$ \\
\hline $\begin{array}{l}\text { Added-value craft } \\
\text { activities (meat, } \\
\text { ceramics, etc.) }\end{array}$ & $\mathbf{3 6 1}$ & $83 \%$ & $43 \%$ & $32 \%$ & $58 \%$ & $71 \%$ & $\mathbf{8 1} \%$ \\
\hline $\begin{array}{l}\text { Ecological farms (pigs, } \\
\text { birds, rabbits, or eggs) }\end{array}$ & $\mathbf{3 2 2}$ & $\mathbf{7 7 \%}$ & $44 \%$ & $52 \%$ & $\mathbf{8 8 \%}$ & $33 \%$ & $\mathbf{2 8 \%}$ \\
\hline
\end{tabular}

Source: the Authors, on the basis of focal groups

1. The first SBO election round in the CHP

Applying the SBO methodology, it can be seen that, in the CHP, cultural activities, when carried out with added value, would have the best SBO for La Cerdanya (87\%) in a reading by columns (places) among the first six A\&LU, although Alta Ribagorça (88\%) would obtain the highest value in a reading by rows. This is an activity that can be carried out in many places if it is known how to link it with restaurant and hotel initiatives (Throsby 2000), as well as others related with landscape quality (Pallares-Blanch 2012). Natural landscape connected with rural tourism (Pallarès-Blanch et al. 2014) would be the the SBO for Alta Ribagorça $(90 \%)$, in the second place, although Era Aran (95\%) would have a higher value for A\&LU. Pasture-fed ecological livestock farming would be the SBO for Pallars Jussà, especially in Vall Fosca (Barrachina et al. 2015), where extensive organically oriented livestock farming can be carried out at low cost if there is cooperation in the butchering and marketing processes (Tulla 2019). The value obtained is the highest for this district when reading by columns $(85 \%)$, although others in the region might do better, for example Pallars Sobirà (89\%) or Alt Urgell (87\%). Adventure tourism would be the SBO for Pallars Sobirà (92\%), although Alt Urgell 
(94\%) shows a higher value by row. In Alt Urgell, milk production gives the highest percentage $(98 \%)$ in the column and also in the row, making it the best place in the region for this activity, which is shown to be competitive internationally as well, thanks to the added value of production and marketing conditions (Tulla et al. 2009). Finally, there are ski resorts with the construction of second homes around them, which would be the SBO for Era Aran (100\%), although La Cerdanya (86\%) is also well positioned for this.

2. The following SBO elections using this methodology

If we were to start a second selection round, we would find that industries, textile design, and services related with sporting materials would be an $\mathrm{SBO}$, in a reading by columns, for Alt Urgell (85\%), which is already the best-placed for this activity (reading by rows). Renewable energy (hydroelectric, solar and wind) is the eighth A\&LU and it would be the SBO for Alta Ribagorça (74\%). Sawmills, the transformation of wood, and the manufacture of pallets represent the SBO for Pallars Sobirà (73\%), although in a reading by rows Alt Urgell $(76 \%)$ would be better positioned. In the CHP, university and professional training centres in the areas of tourism, nursing, and computing would be the SBO for La Cerdanya (81\%), although Alt Urgell (83\%) shows a higher value in a reading by rows. Added-value craft activities of all kinds would suit Era Aran (81\%), although Alt Urgell (83\%) would show a higher value by rows. Ecological pig, bird, rabbit, or egg farms would be the best SBO for Pallars Jussà (88\%), from both the perspectives of place (column) and activity (row).

If more A\&LU were considered, they could be distributed among the districts using the same methodology (Vera Martin and Tulla 2019).

\section{The case of the Principality of Andorra (PA)}

The SBO method was applied in Andorra by using statistical data on the economic activities grouped into 7 sectors (Table 3), and for each of the country's 7 municipalities (Government of Andorra 2018).

Establishments (2016) and wage earners (2017), by economic sector in Andorra

\begin{tabular}{|c|c|c|c|c|c|c|c|c|c|}
\hline \multirow[b]{2}{*}{$\begin{array}{l}\text { Municipalities } \\
\text { Economic } \\
\text { sector }\end{array}$} & $\mathbf{A}$ & B & C & D & $\mathbf{E}$ & $\mathbf{F}$ & $\mathbf{G}$ & & \multirow[b]{2}{*}{$\begin{array}{c}\text { Wage } \\
\text { earners } \\
(2017)\end{array}$} \\
\hline & 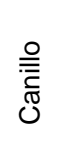 & $\begin{array}{l}\text { 을 } \\
\text { ঠ్ } \\
\text { ஸ் }\end{array}$ & 음 & 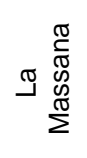 & 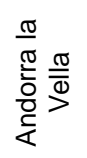 & 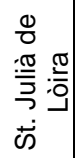 & 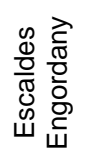 & $\begin{array}{c}\text { Establishment } \\
(2016)\end{array}$ & \\
\hline Agriculture (1) & 49 & 7 & 188 & 443 & 212 & 77 & 315 & 1,291 & 167 \\
\hline Industry (2) & 12 & 3 & 37 & 172 & 139 & 23 & 190 & 576 & 1,604 \\
\hline $\begin{array}{l}\text { Construction } \\
\text { (3) }\end{array}$ & 18 & 5 & 32 & 89 & 62 & 19 & 126 & 351 & 2,875 \\
\hline Transport (4) & 36 & 7 & 97 & 260 & 62 & 53 & 196 & 711 & 1,228 \\
\hline Trade (5) & 43 & 12 & 87 & 221 & 140 & 43 & 379 & 925 & 8,838 \\
\hline Tourism (6) & 155 & 9 & 271 & 1164 & 263 & 126 & 1,070 & 3,058 & 6,301 \\
\hline Services (7) & 62 & 1 & 118 & 532 & 144 & 67 & 521 & 1,445 & 16,698 \\
\hline TOTAL & 375 & 44 & 830 & 2,881 & 1,022 & 408 & 2,797 & 8,357 & 37,711 \\
\hline
\end{tabular}

Abbreviations: (1) Agriculture, livestock farming, and forestry; (2) Industry, energy, and mining; (3) Construction; (4) Transport and communications; (5) Vehicle repair and trade; (6) Hotels, restaurants and tourism; (7) Other services: financial, business, real estate, public administration, social security, education, health, social services, personal services, and others. Source: CASS, Ministry of Finance, Andorra Department of Statistics, and the Authors 
The number of establishments in the economic sector was taken by municipality, in 2016, from the Andorra Department of Statistics, on the assumption that there is one proprietor for each establishment. Wage workers in each economic sector were taken into account and they are distributed by municipalities in accordance with the percentage represented by the number of establishments in each one. Next, the proprietors of establishments are added to the wage workers in each economic sector by municipality, giving the following distribution as a result (Table 4).

Table 4

Economically active population of Andorra, by economic sector and municipality $(2016-2017)$

\begin{tabular}{|l|c|c|c|c|c|c|c|}
\hline $\begin{array}{c}\text { Municipalities } \\
\text { / } \\
\begin{array}{c}\text { Economic } \\
\text { sectors }\end{array}\end{array}$ & A & B & C & D & E & F & G \\
\cline { 2 - 7 } & Canillo & Encamp & Ordino & $\begin{array}{c}\text { La } \\
\text { Massana }\end{array}$ & $\begin{array}{c}\text { Andorra } \\
\text { la Vella }\end{array}$ & $\begin{array}{c}\text { St. } \\
\text { Julià } \\
\text { de } \\
\text { Lòira }\end{array}$ & $\begin{array}{c}\text { Escaldes - } \\
\text { Engordany }\end{array}$ \\
\hline Agriculture (1) & 55 & 8 & 212 & $\underline{\mathbf{5 0 1}}$ & 239 & 87 & $\underline{\mathbf{3 5 6}}$ \\
\hline Industry (2) & 45 & 11 & 140 & $\underline{651}$ & 526 & 87 & $\underline{\mathbf{7 2 0}}$ \\
\hline $\begin{array}{l}\text { Construction } \\
(3)\end{array}$ & 165 & 45 & 294 & $\underline{819}$ & 571 & 174 & $\underline{\mathbf{1 , 3 3 2}}$ \\
\hline Transport (4) & 98 & 19 & 265 & $\underline{\mathbf{7 0 9}}$ & 169 & 144 & $\underline{\mathbf{5 3 5}}$ \\
\hline Trade (5) & 450 & 127 & 918 & $\underline{\mathbf{2 , 3 3 3}}$ & 1,483 & 450 & $\underline{\mathbf{4 , 0 0 2}}$ \\
\hline Tourism (6) & 474 & 28 & 829 & $\underline{\mathbf{3 , 5 6 2}}$ & 805 & 386 & $\underline{\underline{\mathbf{3 , 2 7 5}}}$ \\
\hline Services (7) & 778 & 13 & 1,482 & $\underline{\mathbf{6 , 6 7 7}}$ & 1,807 & 842 & $\underline{\underline{6,540}}$ \\
\hline
\end{tabular}

Abbreviations: As in Table 3. The figures in bold are the highest for the sector, and those in italics show the second highest value for each economic sector

Source: CASS, Ministry of Finance, Andorra Department of Statistics, and the Authors

1. Definition of the statistical framework analysis

The rows correspond to the sectors into which all of Andorra's economic activity has been grouped. The columns respond to the data by administrative unit (municipalities). In bold and underlined, there are the highest values for each sector and, in italics and underlined, there are the second most important values in each sector. In a reading by rows, it appears that all activities prioritize localization in the municipalities of La Massana (4 in first place and 3 in second) and of Escaldes-Engordany (3 in first place and 3 in second). This would suggest a tendency to the concentration of all economic activities in these two territories and the economic and human desertification of the rest of the country. The SBO method can be used in this case, in which only aggregate statistical data are available, as a guide to formulating public policies that would enable other territories to specialize in the activities for which they are best equipped. This would favour a greater diversification of the activity. If we read by columns, seeking for each municipality the sectors in which it is best situated, in both first and second place, these could be considered as an SBO.

\section{The first SBO election}

The value of $100 \%$ is assigned as the highest value of all boxes in the matrix of municipalities/economic sectors and to the remaining boxes is given a percentage value in relation to the highest value. The analysis was carried out based on this resulting matrix in order to identify the SBO for each municipality (Table 5). In order to avoid conflict when assigning sectors to municipalities, we assume that the highest percentage has priority when two or more municipalities coincide in a certain sector. We would start from the municipality that has the value of $100 \%$ (La Massana) and that would correspond to sector 7 (services) as preferential option. It has many services, including health, education, and all kinds of others that have been decentralized from the country's capital Andorra la Vella. 
Moving on, now to Escaldes-Engordany, it is assigned to sector 5 (commerce) since it scores $59.94 \%$, the highest value of the 7 sectors and, so far, it has not corresponded with another municipality. This territory, an urban continuation on the northern side of the capital, is where the greatest part of the country's commercial activities has concentrated, thanks to its good road access.

Next, we see that Ordino would have sector 6 (hotels, restaurants, and tourism) as preferential option since this activity has the municipality's highest percentage $(12.42 \%)$, and commerce and services are excluded as they have previously been assigned to Escaldes-Engordany and La Massana. The municipality of Ordino is important for its natural protected areas (NPA), the Ordino-Arcalis ski resort, and other tourist resources that could be its SBO.

Percentage of Andorra's economically active population,

Table 5 by economic sector and municipality (2016-2017)

\begin{tabular}{|c|c|c|c|c|c|c|c|}
\hline \multirow[b]{2}{*}{$\begin{array}{c}\text { Municipalities } \\
\text { Economic } \\
\text { sectors }\end{array}$} & $\mathbf{A}$ & B & C & D & $E$ & $\mathbf{F}$ & $\mathbf{G}$ \\
\hline & $\begin{array}{c}\text { Canill } \\
0\end{array}$ & $\begin{array}{c}\text { Encam } \\
p\end{array}$ & $\begin{array}{c}\text { Ordin } \\
0\end{array}$ & $\begin{array}{c}\text { La } \\
\text { Massan } \\
\text { a }\end{array}$ & $\begin{array}{c}\text { Andorr } \\
\text { a la } \\
\text { Vella }\end{array}$ & $\begin{array}{l}\text { St. } \\
\text { Julià } \\
\text { de } \\
\text { Lòira }\end{array}$ & $\begin{array}{c}\text { Escaldes - } \\
\text { Engordan } \\
y\end{array}$ \\
\hline Agriculture (1) & 0.82 & 0.12 & 3.18 & 7.50 & 3.58 & 1.30 & 5.33 \\
\hline Industry (2) & 0.67 & 0.16 & 2.10 & 9.75 & 7.88 & 1.30 & 10.78 \\
\hline $\begin{array}{l}\text { Construction } \\
\text { (3) }\end{array}$ & 2.47 & 0.67 & 4.40 & 12.27 & 8.55 & 2.61 & 19.95 \\
\hline Transport (4) & 1.47 & .28 & 3.97 & 10.62 & 2.53 & 2.16 & 8.01 \\
\hline Commerce (5) & $\overline{6.74}$ & 1.90 & 13.75 & 34.94 & 22.21 & 6.74 & 59.94 \\
\hline Tourism (6) & 7.10 & .42 & 12.42 & 53.35 & 12.06 & 5.78 & 49.05 \\
\hline Services (7) & 11.65 & .19 & 22.20 & 100.00 & 27.06 & 12.61 & 97.95 \\
\hline
\end{tabular}

Abbreviations: As in Table 3. Percentages in bold are the best option for each municipality and, in italics, the second best. Both could be seen as the SBO for each municipality.

Source: CASS, Ministry of Finance, Andorra Department of Statistics, and the Authors

The country's capital, Andorra la Vella, shows the highest percentage with sector 3 (construction, $8.55 \%$ ), which would be its preferential option given the sectors and municipalities we have already discussed. The main construction companies are located in this municipality, and it is also where major public works (for example, the sports centre, vertical car parks, the bus station, and so on) have been carried out.

Sant Julià de Lòria, the municipality that is closest to Catalonia, presents the highest percentage in sector $4(2.16 \%)$, transport and communications which, excluding the rows and columns that have already been used, would be its preferential option. This territory has relatively important transport and communication businesses.

In the case of Canillo, with $0.82 \%$ in sector 1 (agriculture) and excluding the sectors and territories we have already dealt with, we would take this as preferential option. This is a municipality with a major investment in extensive livestock farming, which can use large natural meadows and it can also work in the artisanal transformation of dairy products.

Finally, Encamp shows a score of $0.16 \%$ in sector 2 (industry and energy), as preferential option after which other 6 municipalities have made their choices. A good part of the country's hydroelectric energy is produced in this municipality.

3. The following SBO elections using this methodology

If we were now to look for a second sector for each municipality, we would repeat the process from which we would exclude the cells of the matrix that have already been used. Then the 
second-best percentage for Escaldes-Engordany would be in sector 7 (services) with $97.95 \%$ and hence its second preference. This municipality has many educational, financial, and health services, including the Hospital Nostra Senyora de Meritxell which is the country's only public hospital, all of which situates it, together with La Massana, as the most economically significant territory in the country. Both municipalities adjoin Andorra la Vella, which was the country's first urban centre. In La Massana, we find sector 6 (hotels, restaurants, and tourism), with $53.35 \%$. This sector has the La Massana-Pal-Arinsal ski resort, which favours tourist and hotel potential. Then, in Andorra la Vella, sector 5 (commerce) scores $22.21 \%$, and it has a very well-established commercial tradition which has been adapting to new tourist needs. Next, Ordino shows $4.40 \%$ in sector 3 (construction), where expanding tourism has brought about a construction boom. In Canillo, scoring $1.47 \%$ in sector 4 (transport and communications), the proximity to the French border has favoured development here. In Sant Julià de Lòria, with a score of $1.30 \%$ in sector 2 (industry and energy), the tobacco industry coexists alongside other industries of agricultural transformation. Finally, for Encamp, with a score of $0.12 \%$, the agricultural sector has many meadows and natural resources that favour extensive livestock farming.

A third preference could be sought for each municipality using the same method and this would make it possible to design a profile of activities in accordance with the assumption of an SBO for each territory that would be the basis for guiding SLD public policies in the country.

The case of the territory of the Kichwa People of Rukullakta (KPR)

The data used to estimate the SBO for KPR are quantitative (TNC 2018) and qualitative, based on in-depth interviews with experts and by creating focal groups in the 17 communities (Veloz Jaramillo 2019), which reinforce the research (Reichardt and Cook 1979). In each of the comunidades, considered as a territorial unit (Ecofund 2008), there are one or more predios (estates) (Bennett and Sierra 2014), with family or collective activities. Each family possesses a chakra (a productive, organic, and biodiverse space), where ancestral knowledge is applied for self-sufficiency and commercial production.

The Kichwa constitute the largest indigenous group in Ecuador and the Amazon region. They are distributed in small communities that basically live from subsistence agriculture, hunting, and fishing (Erazo 2011). Their forms of organisation enabled them to protect their lands in the face of a growing process of foreign colonisation and, in 1974, the KPR achieved legal recognition as the "San Pedro Limitada" Cooperative for Agricultural and Livestock Production by means of which land tenure was legalised and $17 \mathrm{KPR}$ communities $\left(424.4 \mathrm{~km}^{2}\right.$ and 6,735 inhabitants) were organised. Each community elects a president (Kuraka) and other representatives who meet in a General Assembly when the most important decisions are being made (Erazo 2003). The participation of women, although minority, has been increasing and, recently, a woman was elected as Kuraka of the whole KPR. Rukullakta (which means "the old homeland") is $180 \mathrm{~km}$ southeast of Quito, $2 \mathrm{~km}$ from the town of Archidona, and 12 $\mathrm{km}$ from Tena, the capital of the province of Napo, to which Rukullakta belongs. The town of Loreto, the capital of the province of Orellana, is $60 \mathrm{~km}$ away from the communities in the north of Rukullakta.

The aim of this study is to compare the advantages presented by the comunidades for creating productive activities on the basis of three marketing models: family, local community, and global community. Productive activities are evaluated on the basis of the areas of family cultivation, in accordance with the TNC census (2018), together with the physical conditions and accessibility of each territory. The participation of women has been identified as an indispensable factor for the functioning of the three models, as have been innovation and the creation of added value. 
1. Conditions for the localization of productive activities and their comparative advantages

The optimal localization of productive activities in KPR is conditioned in the ways shown in Fig. 3. The access to the main markets (Archidona and Loreto) for the communities' production favours the implementation of SBO. In this case, forests, occupying $77.55 \%$ of the land and the predominance of agrology class $\mathrm{VI}(72.21 \%)$, which only permits grazing and forestry activities (MAG 2014), represent the main physical limitation. The comunidades have been adapted to these limitations with crops for their own consumption and trading in $4 \%$ of the territory $(1,700.24$ ha.). It is also necessary to consider natural wealth and the diversity of products which vary with the geographical location of the comunidades.

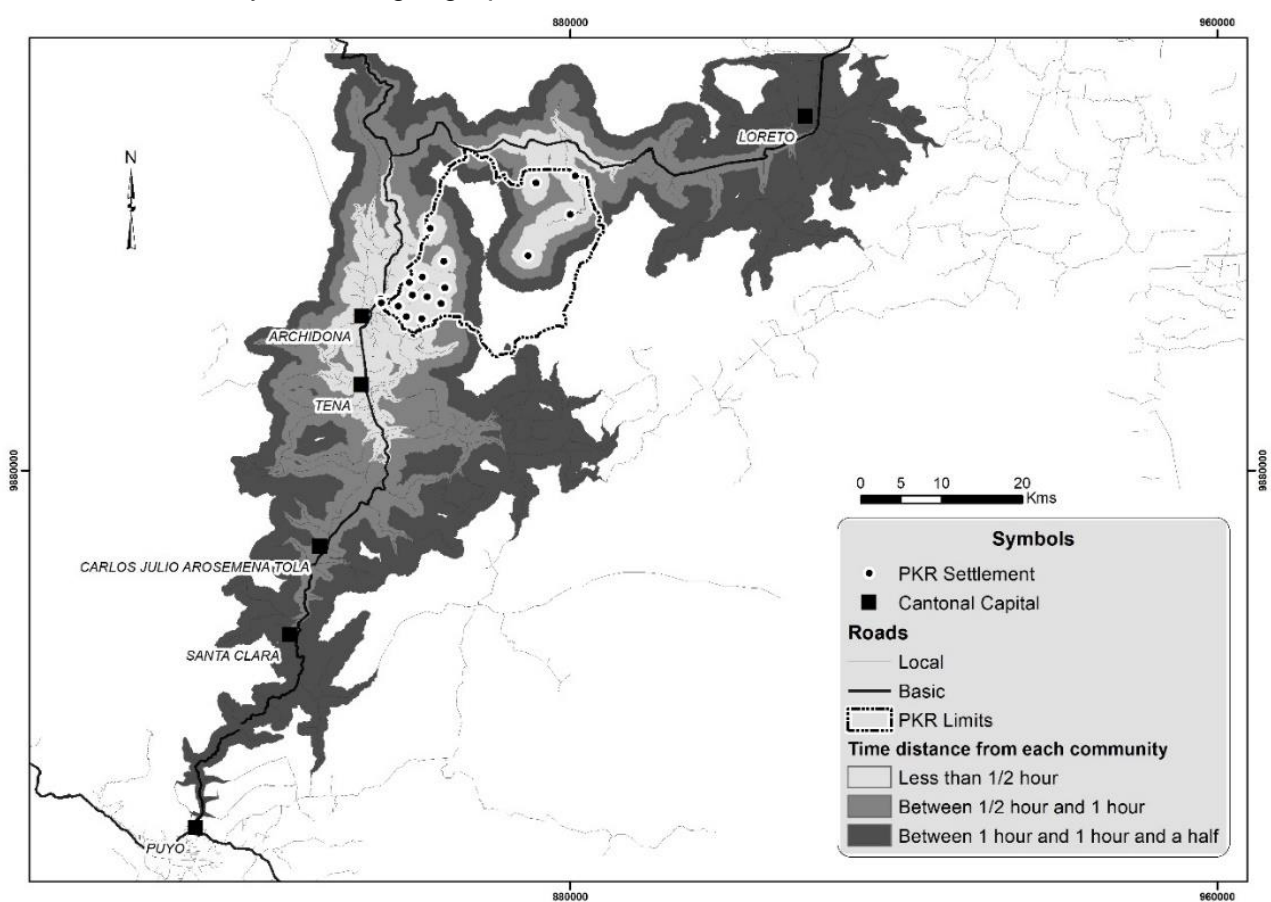

Fig. 3 - Accessibility of KPR communities to main market towns: Archidona and Loreto

Source: the Authors, based on Veloz Jaramillo (2019)

2. SBO for production in the KPR territory

In the SBO method (Table 6), three groups of activities are chosen: agricultural crops, livestock raising, and provision of services. The columns show the KPR comunidades, except for five of them, for which the data is unreliable. We assume that each comunidad has at least one of the three activities and we choose that for which it is best equipped (Tulla et al. 2009). In each comunidad, productive activities are evaluated in accordance with the hectares involved, the number of animals or fish farms in the census (TNC 2018), the conditioning factors of the geographic space, and the kinds of organization of Kichwa families for accessing the regional market.

In Table 6, the most advantageous options for each comunidad in each of the activities appear in bold and underlined. In the family model of activity, the Awayaku (column B), Lushianta (D), Porotoyaku (K), Rukullakta (L), Villano (O) and Yawari (Q) have cacao cultivation as SBO, and Yanayaku (P) has cassava. In Table 7, for a second activity, in italics and underlined, we have cassava for Villano (O). Some comunidades, like Papanku (I), only show activities (in a 
same model) like banana crops, although their preferential SBO would be growing wayusa leaf in the global model.

It can be stated that the cultivation of cacao, cassava and wayusa leaf, together with fishing and poultry raising, is the main SBO in the KPR. In a second round, we would find that growing naranjilla and banana trees, forestry, medicinal herbs, coffee, livestock raising, the Socio Bosque, and tourist services would be possible SBOs in some communities.

Table 6

\section{Comparative advantage and the method of Second-Best Option (SBO),} related to crop surfaces

\begin{tabular}{|c|c|c|c|c|c|c|c|c|c|c|c|c|c|c|}
\hline \multirow{4}{*}{\multicolumn{2}{|c|}{$\begin{array}{c}\text { Community } \\
\text { crops } \\
/ \\
\text { Group of } \\
\text { activities } \\
\text { and models }\end{array}$}} & Comunidad & A & B & D & $\mathbf{F}$ & $\mathbf{G}$ & $\mathbf{H}$ & 1 & $\mathrm{~K}$ & $\mathrm{~L}$ & 0 & $\mathbf{P}$ & $\mathbf{Q}$ \\
\hline & & Inhabitants & $\begin{array}{r}13 \\
8\end{array}$ & $\begin{array}{r}45 \\
8\end{array}$ & 651 & $\begin{array}{r}14 \\
0\end{array}$ & 259 & 303 & 319 & 888 & 820 & 348 & $\begin{array}{r}17 \\
7\end{array}$ & 544 \\
\hline & & $\begin{array}{l}\text { Crop } \\
\text { surface (ha) }\end{array}$ & $\begin{array}{r}20 . \\
0\end{array}$ & $\begin{array}{r}70 . \\
2\end{array}$ & $\begin{array}{r}295 . \\
6\end{array}$ & $\begin{array}{r}46 . \\
7\end{array}$ & 46.8 & 58.1 & $\begin{array}{r}227 . \\
0\end{array}$ & $\begin{array}{r}178 . \\
6 \\
\end{array}$ & 67.2 & 94.0 & $\begin{array}{r}19 . \\
8\end{array}$ & $\begin{array}{r}12 . \\
5 \\
\end{array}$ \\
\hline & & Activity & \multicolumn{12}{|c|}{ Ha or number of animals or number of farms } \\
\hline \multirow[t]{11}{*}{ (a) } & \multirow[t]{9}{*}{$\begin{array}{l}\text { Family } \\
\text { Model }\end{array}$} & $\begin{array}{l}1 \text { Chakra } \\
\text { crops }\end{array}$ & 1.8 & $\begin{array}{r}21 . \\
7\end{array}$ & $\begin{array}{r}135 . \\
1 \\
\end{array}$ & $\begin{array}{r}33 . \\
5\end{array}$ & 9.0 & 18.6 & 68.3 & 78.7 & 18.9 & 12.0 & 4.5 & 5.5 \\
\hline & & $\begin{array}{l}\text { Chakra } \\
\text { cro./inh. }\end{array}$ & $\begin{array}{r}0.0 \\
1\end{array}$ & $\begin{array}{r}0.0 \\
5\end{array}$ & 0.21 & $\frac{0.2}{4}$ & 0.03 & 0.06 & 0.21 & 0.09 & 0.02 & 0.03 & $\begin{array}{r}0.0 \\
3\end{array}$ & $\begin{array}{r}0.0 \\
1\end{array}$ \\
\hline & & 2 Cacao & $\begin{array}{r}10 . \\
8 \\
\end{array}$ & $\frac{39 .}{0}$ & $\underline{85.3}$ & $5 . \overline{5}$ & 12.5 & 20.7 & 16.3 & 43.4 & $\underline{24.8}$ & $\underline{37.3}$ & 1.0 & $\underline{4.5}$ \\
\hline & & 4 Naranjilla & 1.0 & 0.5 & 60.1 & 2.5 & 11.8 & 5.4 & 75.0 & 39.7 & 15.0 & 18.0 & 3.5 & 1.5 \\
\hline & & 6 Banana & 1.5 & 1.5 & 7.8 & 2.0 & 2.0 & 2.0 & 32.8 & 7.2 & 4.0 & 3.8 & 1.0 & 0.0 \\
\hline & & 7 Cassava & 3.3 & 1.5 & 3.3 & 2.8 & 3.0 & 1.8 & 13.8 & 6.4 & 3.3 & 14.5 & 4.8 & 0.5 \\
\hline & & 8 Ticaso & 0.5 & 5.0 & 2.4 & 0.3 & 3.0 & 0.5 & 12.8 & 0.8 & 0.0 & 8.0 & 1.0 & 0.0 \\
\hline & & 9 Forestry & 1.0 & 0.0 & 0.0 & 0.0 & 3.3 & 8.0 & 4.0 & 1.5 & 1.0 & 1.8 & 4.0 & 0.5 \\
\hline & & $\begin{array}{l}10 \text { Medical } \\
\text { herbs }\end{array}$ & 0.3 & 1.5 & 1.4 & 0.0 & 2.3 & 1.1 & 4.0 & 1.0 & 0.3 & 0.8 & 0.0 & 0.0 \\
\hline & \multirow[t]{2}{*}{$\begin{array}{l}\text { Global } \\
\text { Model }\end{array}$} & $\begin{array}{l}3 \text { Wayusa } \\
\text { leaf }\end{array}$ & $\frac{11 .}{3}$ & $\begin{array}{r}12 . \\
6\end{array}$ & 74.8 & $\frac{10 .}{3}$ & $\underline{22.8}$ & $\underline{27.8}$ & 84.5 & 19.6 & 5.9 & 15.3 & 3.5 & 0.0 \\
\hline & & 5 Coffee & 7.9 & $\begin{array}{r}12 . \\
0\end{array}$ & 76.6 & 3.0 & 8.3 & 17.0 & 70.8 & 8.4 & 2.0 & 10.0 & 0.0 & 0.5 \\
\hline \multirow[t]{3}{*}{ (b) } & \multirow[t]{3}{*}{$\begin{array}{l}\text { Commun } \\
\text { ity model }\end{array}$} & $\begin{array}{l}11 \text { Fish } \\
\text { farms }\end{array}$ & 0.0 & 0.0 & 6.0 & 0.0 & 0.0 & 7.0 & 30.0 & 2.0 & $\frac{3,41}{2}$ & $\begin{array}{r}100 . \\
0 \\
\end{array}$ & 0.0 & 0.0 \\
\hline & & $\begin{array}{l}12 \text { Poultry } \\
\text { raising }\end{array}$ & $\frac{91 .}{0}$ & $\frac{50 .}{0}$ & $\frac{743 .}{0}$ & 0.0 & $\frac{318 .}{0}$ & 413. & $\frac{521 .}{0}$ & $\frac{390 .}{0}$ & $\begin{array}{r}252 . \\
0\end{array}$ & $\frac{262 .}{0}$ & $\frac{72 .}{0}$ & $\underline{5.0}$ \\
\hline & & 13 Livestock & 2.0 & 28. & 53.0 & 0.0 & 11.0 & 0.0 & 34.0 & 0.0 & 5.0 & 35.0 & $\begin{array}{r}30 . \\
0\end{array}$ & 0.0 \\
\hline \multirow[t]{2}{*}{ (c) } & \multirow[t]{2}{*}{$\begin{array}{l}\text { Global } \\
\text { Service } \\
\text { Model }\end{array}$} & $\begin{array}{l}14 \\
\text { Environment } \\
\text { (Socio } \\
\text { Bosque) }\end{array}$ & 0.0 & 0.0 & $\begin{array}{r}2,43 \\
4\end{array}$ & 0,0 & $\begin{array}{r}1,43 \\
1\end{array}$ & $\begin{array}{r}1,32 \\
3\end{array}$ & 127 & 934 & 0.0 & $\begin{array}{r}696 . \\
0\end{array}$ & 1.0 & 0.0 \\
\hline & & 15 Tourism & 0.0 & 2.0 & 24.0 & 0.0 & 1.0 & 0.0 & 1.0 & 1.0 & 1.0 & 0.0 & 3.0 & 0.0 \\
\hline
\end{tabular}

Abbreviations: Group of activities - (a) Agricultural; (b) Fishing, poultry and livestock raising; (c) Services.

Comunidades - A, Ardilla Uku; B, Awayaku; D, Lushianta; F, Manku; G, Mushullakta; H, Nukunu; I, Papanku; K, Porotoyaku; L, Rukullakta; O, Villano; P, Yanayaku; and Q, Yawari. Products - (1) Chakra crops; (2) Cacao; (3) Wayusa leaf; (4) Naranjilla; (5) Coffee; (6) Banana; (7) Cassava; (8) Ticaso; (9) Forestry; (10) Medicinal herbs; (11) Fish farms, fishing; (12) Poultry raising; (13) Livestock raising; (14) Environmental services; (15) Tourism.

Sources: the Authors, based on Focal Groups and the TNC Census (2018)

3. Main economic activities applying SBO in KPR

The commercialization of some ancestral products like wayusa, ticaso and yuquilla is the main form of SBO. This activity is based on the added value created with the type of production, Designation of Origin, cultural value, and innovation, which gives them access to a regional or even international market. These products are not very well known outside of Ecuador, but they have managed to enter the world market through social enterprises and international NGOs, as it is the case of wayusa. There are alternatives like cacao, coffee, and naranjilla, which come from the outside, with a higher market value than that of local products, although low production means that they cannot compete on a larger scale. In the cases of cacao and coffee, added value has been achieved with the Designation of Origin and organic production. In the KPR territory, we see that all the comunidades present at least one activity in which they can specialize. 
In Table 7, the number shown in each box corresponds to an activity presented in the rows of Table 6. The columns (SBO) express the best activities (in bold in Tables 6 and 7) that each community can engage in, although they could be done better (higher values) in other comunidades (reading by rows) or outside the KPR territory. The secondary options are shown in italics in Table 7. The results obtained suggest that priority should be given, in the $\mathrm{KPR}$, to cacao and wayusa production, since in almost all comunidades this appears as the largest area of cultivation in the farms, and they can be marketable products.

The SBO method applied to the territory of the Kichwa People of Rukullakta (KPR)

\begin{tabular}{|c|c|c|c|c|c|c|c|c|c|c|c|c|c|}
\hline Priority & Products & \multicolumn{10}{|c|}{ Community } \\
\cline { 3 - 16 } & & A & B & D & F & G & H & I & K & L & O & P & Q \\
\hline 1 & Agricultural & $\mathbf{3}$ & $\mathbf{2}$ & $\mathbf{2}$ & $\mathbf{3}$ & $\mathbf{3}$ & $\mathbf{3}$ & $\mathbf{3}$ & $\mathbf{2}$ & $\mathbf{2}$ & $\mathbf{2}$ & $\mathbf{7}$ & $\mathbf{2}$ \\
\hline 2 & Poultry, fishing & $\mathbf{1 2}$ & $\mathbf{1 2}$ & $\mathbf{1 2}$ & & $\mathbf{1 2}$ & $\mathbf{1 2}$ & $\mathbf{1 2}$ & $\mathbf{1 2}$ & $\mathbf{1 1}$ & $\mathbf{1 2}$ & $\mathbf{1 2}$ & $\mathbf{1 2}$ \\
\hline 3 & Environment & & & 14 & & 14 & 14 & 14 & 14 & & 14 & 14 & \\
\hline 4 & Tourism & & 15 & 15 & & 15 & & 15 & 15 & 15 & & 15 & \\
\hline 5 & Secondary option & & & 5 & & & 9 & 4 & & & 7 & & \\
\hline 6 & Secondary option & & & 13 & & & & 6 & & & & & \\
\hline 7 & Secondary option & & & & & & & 10 & & & & & \\
\hline 8 & Secondary option & & & & & & & 8 & & & & & \\
\hline
\end{tabular}

Abbreviations: as in Table 6.

Source: the Authors, based on Focal Groups and the TNC Census (2018)

The Napo provincial government has promoted the production of chonta (palm weevil) grubs (Chontacuros, larva of Rhynchophorus palmarum) for gastronomic use. The grub is an ingredient of a traditional dish which is served with cassava and garabato yuyo (Hypolepis Hostilis), which are grown on the chakra. According to the focal groups, the grubs are consumed because they have curative properties for respiratory problems and asthma. They are greatly prized in the comunidades to which they are exclusively limited owing to the difficulties of cultivating them, which include cutting down the chonta palms and chopping them into pieces so that the weevil will leave its larvae (which take two months before they are ready for consumption). Hence, their market price is rising because of their scarcity and because of the demand by tourists, the local population, and for export to countries like Colombia, Peru, Brazil, Thailand, and others in Africa.

\section{Discussion}

Taking three different situations - a depopulated region (CHP), a small country (PA), and an Amazonian community (PKR) - it has been possible to demonstrate that there are activities which, even if they are carried out more efficiently in other places, can be the SBO for the studied areas. In most cases, this implies innovation, local development policies, generating added value, and a comparative advantage. In the case of CHP, a mountain area at risk of depopulation, the SBO favours the development of local initiatives supported by public policies, for example tourism and craftwork in their different variants, as alternatives to the economic sector that exists inside and outside the region. In the case of KPR, the method seeks the best possible capacity building for activities in each community, although other territories might be better endowed.

It is important to note that the SBO not only depends on economic factors, but also on the social, cultural and environmental characteristics of each territory. Most local development studies do not take these characteristics into account and, therefore, they do not sufficiently assess the comparative advantages of SBOs. 
In the model for the KPR, the products vary. In family units, agricultural products are prioritized for the local demand, while at community level, animal production is important and, at the global level, the supply of services and agricultural products come in response to the national and international demand. The comparative advantage sought by using the SBO method is the better preparedness of each comunidad for an activity, even if other comunidades are better equipped for it. One aim of the UN is to give support for the products that are most resilient to climate change and, also, to include entomophagy in the diet as a substitute for meat. The FAO regards cassava as a product that is resilient to climate change and one that allows Kichwa communities to eat their own production as well as to sell it. They have infrastructure to create added value through peeling, slicing, packaging, and using residues as a fodder supplement for animals. Another resilient product, the wayusa leaf, is innovative and it has added value since it has infrastructure to make energy drinks and tea with the leaves.

\section{Conclusions}

When neoclassical market principles prevail, the economic development of a region tends to concentrate most activities in a few areas. However, if the aim is not only to obtain economic benefits but also to avoid the depopulation and degradation of the territory, it is necessary to consider other criteria and other methods for the location of an economic activity. The SBO method allows the homogeneous distribution of a territory's activities in accordance with the three premises of comparative advantage in such a way that the distribution of activities is carried out in keeping with the suitability of each territory when confronted with the predominant economic tendency to locate an activity in the zone where it will be most profitable.

The strength of the SBO method resides in the complementarity of the use of qualitative and quantitative methods. However, the result obtained by the means of qualitative techniques is more reliable because they entail intense fieldwork, working with focal groups, and in-depth interviews with agents involved in developing the economic activity and who therefore have a deeper knowledge of the territory. Quantitative methods, however, require a complex database with levels of information that are not always possible to obtain for subsequent econometric calculations or multivariable analysis. When carrying out regional analysis, quantitative methodologies could be more effective, while qualitative methodologies are preferable for local analyses. The cases in this study present different methodologies. For the $\mathrm{CHP}$, only qualitative methodology is used, while in the case of KPR both types of analyses are used in a complementary approach, thus favouring better targeted local development policies. Meanwhile, the PA presents quantitative methodologies with results on a more regional scale, which help the government's political decisions.

As far as we know, there are no other studies using the SBO method for analysing local development. Boadway (1998) applied the method to issues of public economics in relation with the duality of tax policy outcomes. It has also been argued that, although the best legal system is desired, when this is not possible, viable policies should be pursued in the interests of fostering a second-best legislation. Examples of this would be the anti-trust laws (Ulen 1998) and the more general legislation (Markovits 1997). All the studies are based on the premise that, when market competition is not perfect, the SBO method suggests that if some of the distorting elements can be palliated, the economy can develop efficiently (Lypsey and Lancaster 1956). In the cases studied in this paper, the idea of a local or regional reality is applied, recognising constraints like market distortion and seeking the most appropriate activities for each place, despite these limitations.

We can conclude that, in the three cases presented, it has been demonstrated that the SBO method has made it possible to identify the most appropriate economic activities for CHP and $\mathrm{PA}$ in relation with other territories and, in the case of KPR, to diversify the production and, 
thereby, to avoid monocultures and to move beyond subsistence cultivation. This has been possible with the use of primary and secondary data.

\section{References}

BARBOUR R. (2007), Doing Focus Groups, SAGE, London.

BARRACHINA M., CRISTÓBAL J., TULLA A. F. (2015), Estimating Above-Ground Biomass on Mountain Meadows and Pastures through Remote Sensing, International Journal of Applied Earth Observation and Geoinformation 38, 184-192.

BENNETT D. E., SIERRA R. (2014), Multi-Scale Dimensions of Indigenous Land Tenure in the Amazon, Human Ecology 42 (4), 551-563.

BOADWAY R. (1994), The Role of Second-Best Theory in Public Economics, Working Papers 910, Queen's University, Kingston.

BOADWAY R. (1998), Public Economics as Second-Best Analysis, in: Wolf H. C. (ed.), Contemporary Economic Issues. Macroeconomics and Finance, Palgrave Macmillan, London, pp. 118-137.

BOHM P. (1987), Second Best, in: Eatwell J., Milgate M., Newman P. (eds.), The New Palgrave: A Dictionary of Economics, Palgrave Macmillan, London, pp. 280-283.

BRICALL J. M., BARTUMEU MARTÍNEZ I., PONS NOVELL J. (2001), L'economia andorrana en el canvi de segle, Fundació Julià Reig, Andorra.

BRICALL J. M., CAMPS C., CULLELL J. M., FARRÉ-ESCOFET E. P., PETITBÓ A., SOGUES J., TOMÀS R. (1975), Estructura i perspectives de l'economia andorrana. Estudi preparatori de planificació encarregat pel M.I. Consell General de les Valls d'Andorra, Edicions 62, Barcelona.

CREȚAN R., GURAN-NICA L., PLATON D., TURNOCK D. (2005), Foreign Direct Investment and Social Risk in Romania: Progress in Less-Favoured Areas, in: Turnock D. (ed.), Foreign Direct Investment in Eastern Europe, Ashgate, London, pp. 305-348.

CREȚAN R., JUCU S., ANTONI M. (2016), Anisotropic Spaces in Romania: A Case Study of the Timiș-Cerna Corridor, Acta geographica Slovenica 56 (1), 45-56.

CREȚAN R., TURNOCK D., WASSING M. (2009), Romania's Airlines and Airports during Transition with Particular Reference to the West Region, Mitteilungen der Österreichischen Geographischen Gesellschaft 151 (1-2), 241-276.

CREȚAN R., O'BRIEN T. (2020), Corruption and Conflagration: (In)Justice and Protest in Bucharest after the Colectiv Fire, Urban Geography 41 (3), 368-388.

CREȚAN R., VESALON L. (2017), The Political Economy of Hydropower in the Communist Space: Iron Gates Revisited, Tijdschrift voor Economische en Sociale Geografie 108 (5), 688-701.

DE MARCO LARRAURI O., PÉREZ NEIRA D., SOlER MONTIEL M. (2016), Indicators for the Analysis of Peasant Women's Equity and Empowerment Situations in a Sustainability Framework: A Case Study of Cacao Production in Ecuador, Sustainability 8 (12), 1231.

ECOFUND (2008), Pueblo Kichwa de Rukullakta. Plan de Manejo, Retrieved from: www.ecofund.org.

ERAZO J. S. (2003), Constructing Autonomy: Indigenous Organizations, Governance, and Land Use in the Ecuadorian Amazon, 1964-2001, University of Michigan, Michigan.

ERAZO J. S. (2011), Landscape Ideologies, Indigenous Governance, and Land Use Change in the Ecuadorian Amazon, 1960-1992, Human Ecology 39, 421-439.

FINDLAY R., HENRIKSSON R. G. H., LINDGREN H., LUNDAHL M. (2016), Eli Heckscher, International Trade, and Economic History, The MIT Press, London.

FULLER A. M. (1990), From Part-Time Farming to Pluriactivity: A Decade of Change in Rural Europe, Journal of Rural Studies 6 (4), 361-373.

GOVERNMENT OF ANDORRA (2018), Andorra en Xifres 2018, Departament d'Estadística, Andorra la Vella.

GRAY C. L., BILSBORROW R. E., BREMNER J. L., LU F. (2008), Indigenous Land Use in the Ecuadorian Amazon: A Cross-Cultural and Multilevel Analysis, Human Ecology 36, 97-109. 
HALL P. (ed.) (1966), Von Thünen's 'Isolated State', Pergamon Press, Oxford.

IANOȘ I. (2000), Less-Favoured Areas and Regional Development in Romania, in: Horváth G. (ed.), Regions and cities in the global world: Essays in honour of Gyorgy Enyedi, Centre for Regional Studies. Hungarian Academy of Sciences, Pécs, pp. 176-191.

IDESCAT (2018), Anuari de l'Institut d'Estadística de Catalunya 2018, Generalitat de Catalunya, Barcelona. London.

KRUEGER R. A. (1998), Analyzing \& Reporting Focus Groups Results, SAGE,

KRUEGER R. A., CASEY M. A. (2014), Focus Groups: A Practical Guide for Applied Research, SAGE, London.

LEE R., SMITH D. M. (eds.) (2004), Geographies and Moralities: International Perspectives on Development, Justice and Place, Blackwell, Oxford.

LIPSEY R. G., LANCASTER K. (1956), The General Theory of Second Best, Review of Economic Studies 24 (1), 11-32.

LIPSEY R. G. (2007), Reflections on the General Theory of Second Best at its Golden Jubilee, International Tax and Public Finance 14, 349-364.

MAG (2014), Mapa de uso y cubiertas del suelo, Ministerio de Agricultura y Ganadería, Gobierno de Ecuador, Quito.

MARKOPOULOS T. (2019), Common Agricultural Policy and Local Economy and Development in the Region of Eastern Macedonia-Thrace (Greece), Journal of Engineering Science and Technology Review 12 (2), 185-223.

MARKOVITS R. S. (1997), Second-Best Theory and Law \& Economics: An Introduction, Chicago-Kent Law Review 73 (1), 3-10.

MOCANU I., GRIGORESCU I., MITRICĂ B., POPOVICI E.-A., DUMITRAȘCU M. (2018), Regional Disparities Related to Socio-Economic Determinants of Agriculture in the Romanian Plain, Journal of Urban and Regional Analysis 10 (1), 79-99.

MORGAN D. L. (1998), The Focus Group Guidebook, SAGE, London. London.

MYRDAL G. (1957), Economic Theory and Under-Developed Regions, Duckworth,

NEL.LO O. (2010), The Challenges of Urban Renewal. Ten Lessons from the Catalan Experience, Análise Social 45 (197), 685-715.

O'BRIEN T., CRETAN R. (2019), The Role of Identity in the 2015 Romanian Shepherd Protests, Identities 26 (4), 470-488. London.

OHLIN B. (1933), Interregional and International Trade, Harvard University Press,

OLSEN E. (1971), International Trade Theory and Regional Income Differences: United States 1880-1950 (Contributions to economic analysis), North-Holland, Amsterdam.

PALLARES-BARBERA M., TULLA A. F., VERA A. (2004), Spatial Loyalty and Territorial Embeddedness in the Multi-Sector Clustering of the Berguedà Region in Catalonia (Spain), Geoforum 35 (5), 635-649.

PALLARES-BLANCH M. (2012), Natural Protected Areas and Rural/Local Development: A Sustainable Strategy in Remote Areas, Urbani izziv 23 (S2), S87-S96.

PALLARÈS-BLANCH M., PRADOS VELASCO M.-J., TULLA PUJOL A. F. (2014), Naturbanization and Urban-Rural dynamics in Spain: Case Study of New Rural Landscapes in Andalusia and Catalonia, European Countryside 6 (2), 118 - 160.

POU SERRADELL V. (eds.) (2005), La balança de fets $i$ pagaments del Principat d'Andorra, Centre de Recerca d'Afers Exteriors. Govern d'Andorra, Andorra.

REICHARDT C. S., COOK T. D. (1979), Beyond Qualitative versus Quantitative Methods, in: Cook T. D., Reichardt C. S. (eds.), Qualitative and Quantitative Methods in Evaluation Research, Sage, Beverly Hills, CA, pp. 7-32.

RICARDO D. (1817), On the Principles of Political Economy and Taxation, Cambridge University Press, Cambridge. London.

SMITH D. M. (1977), Human Geography: A Welfare Approach, Edward Arnold,

SAGE, London.

STEWART D. W., SHAMDASANI P. N. (2014), Focus Groups: Theory and Practice, 
THE NATURE CONSERVANCY (TNC) (2018), Censo, The Nature Conservancy NGO, Quito.

THROSBY D. (2000), Economics and Culture, Cambridge University Press, Cambridge.

TULLA A. F. (2019), Sustainable Rural Development Requires Value-Added Activities Linked with Comparative Advantage: The Case of the Catalan Pyrenees, European Countryside 11 (2), 229-256.

TULLA A. F., PALLARES-BARBERA M., VERA A. (2009), Naturbanization and Local Development in the Mountain Areas of the Catalan Pyrenees, in: Prados M. J. (ed.), Naturbanization: New Identities and Processes for Rural-Natural Areas, Taylor \& Francis, London, pp. 75-92.

TULLA A. F., VERA A., BADIA A., GUIRADO C., VALLDEPERAS N. (2014), Rural and Regional Development Policies in Europe: Social Farming in the Common Strategic Framework (Horizon 2020), Journal of Urban and Regional Analysis 6 (1), 35-52.

ULEN T. S. (1998), Courts, Legislatures, and the General Theory of Second Best in Law and Economics, Chicago-Kent Law Review 73 (1), 189-220.

VELOZ JARAMILLO G. E. (2019), Modelo de asociatividad para el desarrollo sostenible de territorios indígenas de la Amazonía Ecuatoriana. El caso del Pueblo Kichwa Rukullakta, Universitat Autònoma de Barcelona, Bellaterra.

VERA A., BADIA A., TULLA A. F. (2011), Desarrollo local en el Pirineo Catalán. Impulso económico y uso sostenible del territorio, Finisterra 46 (92), 5-23.

VERA MARTIN A., TULLA A. F. (2019), Innovation, Spatial loyalty, and ICTS as Locational Determinants of Rural Development in the Catalan Pyrenees, European Countryside 11 (4), 517-540.

VESALON L., CRETAN R. (2012), Development-Induced Displacement in Romania: The Case of Roşia Montană Mining Project, Journal of Urban and Regional Analysis 4 (1), 63-75.

Initial submission: 09.12.2020

Revised submission: 06.04.2021

Final acceptance: 15.04 .2021

Correspondence: Department of Geography, Institut de Ciència i Tecnologia Ambiental (ICTA), Universitat Autònoma de Barcelona (UAB), Campus de la UAB, Plaça Cívica, 08193 Bellaterra, Barcelona, Spain.

Email: antoni.tulla@uab.cat 